\title{
A comparative analysis of the effects of landfills on water quality: a case study of two locations in New Jersey
}

\section{Análisis comparativo de los efectos de los rellenos sanitarios en la calidad del agua: estudio de caso de dos localidades en New Jersey}

\author{
Zarlasht Abubakr ${ }^{1}$, Casilda Saavedra ${ }^{2 *}$ \\ ${ }^{1}$ Wilkes University, ${ }^{2}$ Universidad Tecnológica de Panamá
}

\begin{abstract}
Leachate is a liquid generated by mixing of water with organic and inorganic material found in landfills. This liquid accumulates at the bottom of the landfill and has the potential to percolate through the soil to enter groundwater or other water bodies. Leachate contains various contaminants and toxins that can significantly diminish the quality of water it enters, which can become hazardous to humans and the environment. In this article, the water quality of two towns: Egg Harbor and Middle Township, New Jersey were analyzed and compared. Egg Harbor Township has a landfill located within the town, while the closest landfill to Middle Township is approximately 10 miles away. Water supply for both towns comes from the same aquifer, known as the KirkwoodCohansey water table system. The water quality results from community wells within Egg Harbor Township were compared to those of Middle Township. Water quality data for this study is from New Jersey American Water database. Based on the results, the water quality of Egg Harbor Township varies significantly from Middle Township. The levels of contaminants in Egg Harbor Township are much higher compared to Middle Township. Therefore, it can be concluded that communities near landfills, even well monitored and managed ones, are prone to have poorer water quality than those farther away from the landfill.
\end{abstract}

Keywords Landfill, Water Quality, Egg Harbor Township, Middle Township, New Jersey State.

Resumen El lixiviado es un líquido generado por la mezcla de agua con material orgánico e inorgánico que se encuentra en los rellenos sanitarios. Este líquido se acumula en la parte inferior del relleno sanitario y tiene el potencial de percolarse a través del suelo para ingresar al agua subterránea u otros cuerpos de agua. El lixiviado contiene diversos contaminantes y toxinas que pueden disminuir significativamente la calidad del agua en la que ingresa, lo que puede ser peligroso para los seres humanos y el medio ambiente. En este artículo, se analizó y comparó la calidad del agua de dos ciudades: Egg Harbor y Middle Township, ubicadas en New Jersey. Egg Harbor Township tiene un relleno sanitario ubicado dentro de la ciudad, mientras que el relleno más cercano a Middle Township se encuentra a aproximadamente 10 millas de distancia. El suministro de agua para ambas ciudades proviene del mismo acuífero, conocido como el sistema de nivel freático de Kirkwood-Cohansey. Los resultados de la calidad del agua de los pozos comunitarios en Egg Harbor Township se compararon con los de Middle Township. Los datos de calidad del agua para este estudio provienen de la base de datos de New Jersey American Water. Según los resultados, la calidad del agua de Egg Harbor Township varía significativamente de la de Middle Township. Los niveles de contaminantes en Egg Harbor Township son mucho más altos en comparación con Middle Township. Por lo tanto, se puede concluir que las comunidades cercanas a los vertederos, incluso las que están bien monitoreadas y gestionadas, tienden a tener una calidad de agua más pobre que las que están más lejos del relleno sanitario.

Palabras clave Relleno sanitario, calidad de agua, Egg Harbor, Middle Township, Estado de New Jersey.

* Corresponding Author: casilda.saavedra@utp.ac.pa

\section{Introduction}

\subsection{Site information}

A landfill is a designated site that is used to bury various solid waste materials. As time progresses, the waste that is buried in the landfill decomposes and produces gases such as methane. Various weather conditions such as snow and precipitation seep through the landfill cover and form toxic soot with the waste, which is known as leachate [1]. If the landfill is not properly monitored or managed, the waste products can enter the air, soil, surface and subsurface water 
bodies and create environmental and health problems [2]. The focus of this research is to analyze water quality data of potable groundwater supply to residential areas near and farther away from a landfill. It is hypothesized that the water quality of residential areas near operating or closed landfills are diminished due to close proximity and possible leachate percolation to groundwater compared to residential areas farther away from a landfill.

The two residential towns that will be analyzed include Egg Harbor Township located in Atlantic County, New Jersey, and Middle Township located in Cape May County, New Jersey. The Egg Harbor Township consists of an operating landfill known as the ACUA Landfill, which accepts various waste such as animal waste, non-friable asbestos, construction and demolition waste, carpet material, contaminated soil, dry industrial waste, asphalt, concrete, municipal solid waste, ash, recyclables, sludge, tires from trucks and tractor, and wood [3]. This town's water supply comes from a public community water system consisting of 23 wells, which comes from an 800foot sand aquifer known as the Kirkwood-Cohansey water table system [4].

Middle Township does not have a landfill located within the town. In fact, the closest landfill is approximately 10 miles away from the town, known as the CMCMUA Landfill [3]. The water supply system for this town comes from 3 wells and 1 purchased groundwater source known as the Wildwood Water. The well water comes from the same 800-foot sand aquifer, Kirkwood-Cohansey water table system, which also supplies the Egg Harbor Township [4].

\subsection{Water quality parameter standards}

Table 1 summarizes a list of contaminants that are addressed in this article and their Maximum Contaminant Level allowed in drinking water supplies, defined by U.S. Environmental Protection Agency (EPA) [5].

Table 1. Maximum Contaminant Level Allowed by EPA for Each Parameter

\begin{tabular}{lc}
\hline \multicolumn{1}{c}{ Parameter } & MCL \\
\hline Chlorine (ppm) & 4 \\
Copper (ppm) & 1.3 \\
Chromium (ppb) & 100 \\
Fluoride (ppm) & 4 \\
Iron (ppm) & 0.3 \\
Lead (ppb) & 15 \\
Manganese (ppm) & 0.05 \\
Mercury (ppb) & 2 \\
Nickel (ppb) & 100 \\
Nitrate (ppm) & 10 \\
Sodium (ppm) & 50 \\
\hline
\end{tabular}

**MCL: Maximum Contaminant Level.

\subsection{Contaminants of concern}

The common contaminants that were analyzed in this article include chlorine, copper, fluoride, iron, lead, nitrate, and sodium. Chlorine has a maximum contaminant level of $4 \mathrm{ppm}$, defined by EPA [5]. Chlorine is added to water as a disinfectant. Exceeding the limit in drinking water can cause eye and nose irritation, as well as stomach discomfort [5].

The EPA action level for copper is $1.3 \mathrm{ppm}$ [5]. The presence of copper in water is an indicator of waste generated from various industrial activities. Excess copper in drinking water can cause digestive distress, liver and kidney damage, and anemia [5].

Furthermore, EPA has set a maximum contaminant level of 4 ppm for fluoride in drinking water [1]. Excess fluoride levels in water can cause bone disease and mottled teeth in children [1].

Iron has a maximum contaminant level of $0.3 \mathrm{ppm}$ that is allowed in drinking water supplies [5]. If this level is surpassed, it can create a discoloration and bitter taste in water. Iron can occur naturally in water bodies from sediments and rocks, or it can be added by anthropogenic activities such as mining, industrial waste or corroding metal [5].

Additionally, lead is an important parameter to constantly monitor because it can cause many adverse health effects to humans including low blood cell count, physical and mental abnormalities in children, blood pressure fluctuation in adults and more. The action level for lead defined by EPA is $15 \mathrm{ppb}$ [5].

The maximum concentration of nitrate allowed in drinking water is $10 \mathrm{ppm}$ [5]. Nitrate occurs in water naturally, however, highest levels are found in groundwater under extensively developed areas. It can enter a water body through the use of fertilizers, leachate from landfills, open dumpsites or sewage. An excess amount of nitrogen can cause blue baby disease, which affects the oxygen-carrying capacity of the blood [5].

The standard range of sodium allowed in drinking water is between 30 to $60 \mathrm{ppm}$. Exceeding this range can be a health risk for individuals on a low sodium diet.

\subsection{Typical water quality information for the sites}

Typical water quality data obtained from New Jersey American Water for both Egg Harbor Township and Middle Township lists the following parameters: $\mathrm{pH}$, total hardness, fluoride, sodium, iron, manganese, lead, copper, nitrate, arsenic, and chromium (see table 2 and table 3) [4].

Table 2. Typical Water Quality Information for Egg Harbor Township Located in Atlantic County, New Jersey

\begin{tabular}{lll}
\hline \multicolumn{1}{c}{ Parameter } & Average & MCL \\
\hline$p H$ & $6.6-7.9$ & --- \\
Total Hardness & $31-100 \mathrm{ppm}$ & --- \\
Fluoride & ND $-0.2 \mathrm{ppm}$ & $4.0 \mathrm{ppm}$ \\
Sodium & 4.8 to $69.4 \mathrm{ppm}$ & N/A \\
\hline
\end{tabular}




\begin{tabular}{lll}
\hline Iron & $\mathrm{ND}-0.72 \mathrm{ppm}$ & $0.3 \mathrm{ppm}$ \\
Manganese & $\mathrm{ND}-0.04 \mathrm{ppm}$ & $0.05 \mathrm{ppm}$ \\
Lead & $4 \mathrm{ppb}$ & $15 \mathrm{ppb}$ \\
Copper & $0.392-0.411 \mathrm{ppm}$ & $1.3 \mathrm{ppm}$ \\
Nitrate & $\mathrm{ND}-3.63 \mathrm{ppm}$ & $10 \mathrm{ppm}$ \\
Arsenic & $\mathrm{ND}$ & $5 \mathrm{ppb}$ \\
Chromium & $\mathrm{ND}-0.26 \mathrm{ppb}$ & $100 \mathrm{ppb}$ \\
\hline
\end{tabular}

** ND - Not Detected.

Table 3. Typical Water Quality Information for Middle Township Located in

\begin{tabular}{lll}
\multicolumn{1}{c}{ Parameter } & A verage & MCL \\
\hline pH & $7.19-8.36$ & --- \\
Total Hardness & $47-61 \mathrm{ppm}$ & --- \\
Fluoride & $\mathrm{ND}-0.2 \mathrm{ppm}$ & $4.0 \mathrm{ppm}$ \\
Sodium & $9.14-67.6 \mathrm{ppm}$ & $\mathrm{N} / \mathrm{A}$ \\
Iron & $\mathrm{ND}-0.42 \mathrm{ppm}$ & $0.3 \mathrm{ppm}$ \\
Manganese & $\mathrm{ND}-0.05 \mathrm{ppm}$ & $0.05 \mathrm{ppm}$ \\
Lead & $2 \mathrm{ppb}$ & $15 \mathrm{ppb}$ \\
Copper & $0.125 \mathrm{ppm}$ & $1.3 \mathrm{ppm}$ \\
Nitrate & $\mathrm{ND}-0.02 \mathrm{ppm}$ & $10 \mathrm{ppm}$ \\
Arsenic & $\mathrm{ND}$ & $5 \mathrm{ppb}$ \\
Chromium & $\mathrm{ND}$ & $100 \mathrm{ppb}$ \\
\hline
\end{tabular}

The average $\mathrm{pH}$ range in Egg Harbor Township water is between 6.6 and 7.9. The standard range for $\mathrm{pH}$ required by U.S. Environmental Protection Agency (EPA) for drinking water is within 6.5 to 8.5 [5]. Therefore, this site meets the standard for $\mathrm{pH}$. The average $\mathrm{pH}$ range for Middle Township is between 7.19 and 8.36, which also falls in the range required by EPA.

Hardness in water can decrease the effectiveness of soap and other detergents, as well as increase scale formation in heaters and boilers. The total hardness for the Egg Harbor Township is between 31 to $100 \mathrm{mg} / \mathrm{L}$ as $\mathrm{CaCO} 3$. This indicates that the water ranges from soft to moderately hard [5]. This facility must take additional steps to reduce hardness in the drinking water to avoid these problems. Moreover, the total hardness in Middle Township water supplies ranges between 47 and $61 \mathrm{mg} / \mathrm{L}$ as $\mathrm{CaCO} 3$, which would be considered as soft water by EPA [5].

Excess manganese in water can cause discoloration, staining, and metallic taste [5]. It can occur in drinking water from natural sources such as soil and rocks or added to groundwater through underground pollution such as leachate percolation. A maximum level of manganese allowed in drinking water is $0.05 \mathrm{ppm}$ [5]. The average level of manganese for Egg Harbor Township ranges from "not detected" to $0.04 \mathrm{mg} / \mathrm{L}$, while in Middle Township, it ranges from "not detected" to $0.05 \mathrm{mg} / \mathrm{L}$. This suggests that both sites have high manganese content that could be due to the geology of the area or possibility of groundwater pollution (see table 2 and table 3).

Arsenic can be used as an indicator of groundwater contamination from leachate percolation, but New Jersey American Water did not provide data for the typical concentration of arsenic in either one of these sites. However, chromium is typically detected in Egg Harbor Township in levels of up to $7.3 \mathrm{ppb}$. Although the highest concentration detected level is below the standard of $100 \mathrm{ppb}$ [5], continuous exposure can cause severe health effects on skin and possibly other parts of the body. Moreover, the presence of chromium in water can be linked to leachate percolation or inadequate industrial waste disposal practices in Egg Harbor Township.

\section{Methodology}

\subsection{Databases}

- Water quality data for Egg Harbor Township and Middle Township was collected from New Jersey American Water.

- Data for health effects of contaminants was obtained from the U.S. Environmental Protection Agency.

- Data for parameter standards were obtained from the U.S. Environmental Protection Agency.

- Annual water quality data for 2014, 2015, and 2016 for Egg Harbor Township and Middle Township was collected from New Jersey American Water.

- Water quality dada was analyzed with reference to the Standards for the US, but also a comparative analysis was done of the conditions for the two towns included in this study.

\section{Results}

Table 4. Annual Water Quality Information for Treated Water Supply of Egg

\begin{tabular}{ccccc}
\hline \multicolumn{4}{c}{ Harbor Township and Middle Township, New Jersey } \\
\hline $\begin{array}{c}\text { Paramet } \\
\text { er }\end{array}$ & $\begin{array}{c}\text { HDL } \\
\text { Year }\end{array}$ & $\begin{array}{c}\text { Egg Harbor } \\
\text { Township }\end{array}$ & $\begin{array}{c}\text { Middle } \\
\text { Township }\end{array}$ & $\begin{array}{c}\text { Percent } \\
\text { Difference (\%) }\end{array}$ \\
\hline $\begin{array}{c}\text { Chlorine } \\
\text { (ppm) }\end{array}$ & 2014 & 0.62 & 0.62 & 0.00 \\
& 2015 & 0.73 & 0.67 & 8.57 \\
& 2016 & 0.76 & 0.74 & 2.67 \\
$\begin{array}{c}\text { Copper } \\
\text { (ppm) }\end{array}$ & 2014 & 0.354 & 0.087 & 121.09 \\
& 2015 & 0.354 & 0.086 & 121.82 \\
& 2016 & 0.354 & 0.086 & 121.82 \\
Fluoride & 2014 & 0.16 & 0.26 & -47.62 \\
(ppm) & 2015 & 0.16 & 0.2 & -22.22 \\
& 2016 & 0.16 & 0.2 & -22.22 \\
Iron & 2014 & 0.76 & 0.43 & 55.46 \\
(ppm) & 2015 & 0.4 & 0.42 & -4.88 \\
& 2016 & 0.23 & 0.42 & -58.46 \\
\hline
\end{tabular}




\begin{tabular}{ccccc}
\hline $\begin{array}{c}\text { Lead } \\
(p p b)\end{array}$ & 2014 & 2 & 2 & 0.00 \\
& 2015 & 2 & 1 & 66.67 \\
& 2016 & 2 & 1 & 66.67 \\
Nitrate & 2014 & 3.29 & 0.01 & 198.79 \\
$($ ppm $)$ & 2015 & 3.38 & 0.01 & 198.82 \\
& 2016 & 3.34 & 0.01 & 198.81 \\
\multirow{2}{S}{$\begin{array}{c}\text { Sodium } \\
\text { (ppm) }\end{array}$} & 2014 & 55.7 & 63 & -12.30 \\
& 2015 & 74.1 & 66.6 & 10.66 \\
& 2016 & 68.6 & 67.1 & 2.21 \\
\hline
\end{tabular}

**HLD: Highest Level Detected.

Percent Difference between parameters of the two sites was calculated. Figure 1 shows the water quality values for a period of three years for Egg Harbor Township, New Jersey, while figure 2 shows the same information for Middle Township, New Jersey.

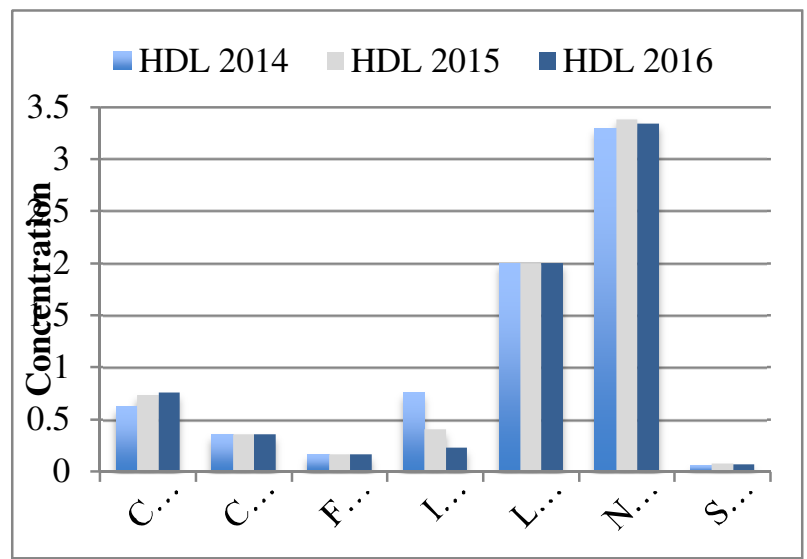

Figure 1. Summary of parameters' highest detected levels over the three-year period for Egg Harbor Township, New Jersey.

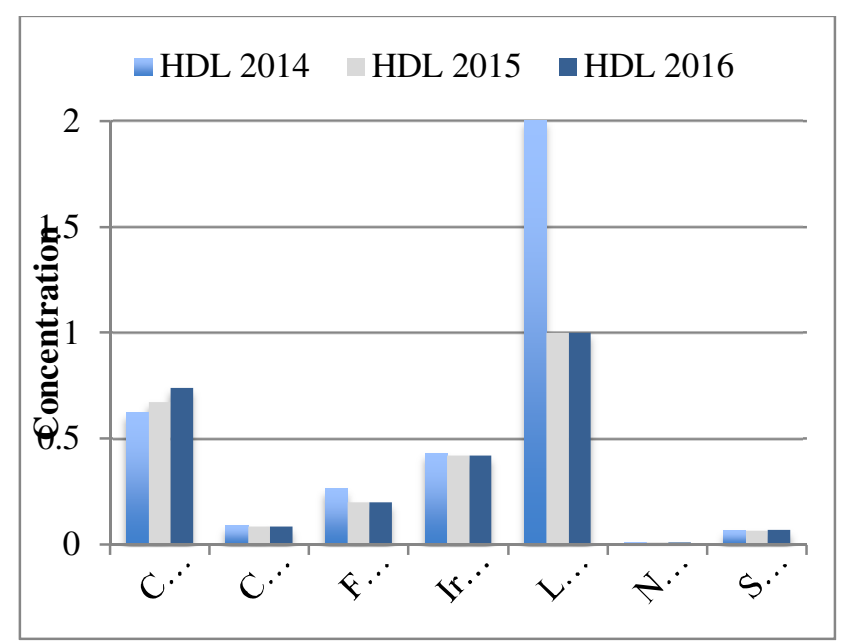

Figure 2. Summary of parameters' highest detected levels over the three-year period for Middle Township, New Jersey.

Table 5. Additional Parameters Measured Annually for Treated Water Supply in Egg Harbor Township

\begin{tabular}{ccc}
\hline Parameter & HDL Year & Egg Harbor Township \\
\hline Barium & 2014 & 0.2 \\
(ppm) & 2015 & 0.2 \\
& 2016 & 0.2 \\
\hline $\begin{array}{c}\text { Chromium } \\
\text { (ppb) }\end{array}$ & 2014 & 7.3 \\
\hline & 2015 & 7.3 \\
\hline Manganese & 2016 & 7.3 \\
(ppm) & 2014 & 0.081 \\
& 2015 & 0.026 \\
\hline Mercury & 2016 & 0.011 \\
(ppb) & 2014 & 0.5 \\
& 2015 & 0.5 \\
\hline Nickel & 2016 & 0.5 \\
(ppb) & 2014 & 7 \\
& 2015 & 7 \\
\hline
\end{tabular}

\section{Discussions}

The contaminants of concern listed in table 4 were the main focus in data analysis of this article. During the three-year period, the chlorine concentration increased from 0.62 to 0.76 in Egg Harbor Township, and from 0.62 to 0.72 in Middle Township (see table 4). This indicates that the use of chlorine to disinfect water increased for both sites.

Over the three-year period, the copper concentration in Egg Harbor Township remained at $0.354 \mathrm{ppm}$, while water in Middle Township decreased in concentration from 0.087 to $0.086 \mathrm{ppm}$. Although both sites meet the standard set for copper, taking steps to reduce their amount in drinking water prevents accumulation of these harmful metals in the body that can cause damage over time.

Both of the sites meet the standard set for fluoride since the concentrations over the three years for this parameter was very low for both sites. Therefore, the potential adverse health effects that can be caused by elevated fluoride levels can be disregarded and no further action is required to reduce these levels.

Furthermore, Egg Harbor Township has a typical maximum iron concentration of $0.72 \mathrm{ppm}$ (see table 2). The iron concentration in this site can exceed the standard by more than two folds, which suggests that there may be sources near this drinking water supply that contributes to the elevated levels of iron. Since a landfill and a Superfund site are located in the Egg Harbor Township, they can be contributing to the 
elevated levels of iron in the drinking water. Moreover, the landfill accepts various wastes, including industrial and municipal solid waste that can contain materials rich in iron. This can also indicate possible groundwater contamination from leachate generated in the operating landfill and the Superfund site. The typical maximum iron concentration for Middle Township is $0.42 \mathrm{ppm}$, which also exceeds the standard.

The typical concentration of lead in Egg Harbor Township water is $4 \mathrm{ppb}$ (see table 2), whereas the Middle Township has a typical concentration of $2 \mathrm{ppb}$ (see table 3). The action level for lead is $15 \mathrm{ppb}$, but when it comes to drinking water, it is highly preferable for lead concentration to be insignificant. Lead has the potential to accumulate in an individual's body and cause health problems over time. The presence of higher amount of lead in Egg Harbor Township could be due to a close proximity of the ACUA landfill and a Superfund site to the town, hence affecting its water resources.

The maximum typical nitrate concentration is $3.63 \mathrm{ppm}$ in Egg Harbor Township water supplies, while in Middle Township, it ranges from "not detected" to $0.02 \mathrm{ppm}$. Both sites maintain values under the standard level, but Egg Harbor Township has a much higher nitrate level. In order to prevent the harmful effects of elevated nitrate over time, it would be ideal to make the allowable nitrate levels stricter for Egg Harbor Township water supplies.

The Egg Harbor Township water typically contains an average sodium concentration range of 4.8 to $69.4 \mathrm{ppm}$, and the Middle Township ranges between 9.14 to $67.6 \mathrm{mg} / \mathrm{L}$. Both sites sometimes exceed the maximum contaminant level set by the EPA, which can be a health risk for individuals on a low sodium diet.

The three-year average data closely match the typical levels listed for all of these parameters. However, there are several parameters that were measured in the 3-year annual period for Egg Harbor Township, which include barium, chromium, manganese, mercury, and nickel (see table 5). These parameters were not measured for Middle Township. All of these parameters were below the standard defined by the EPA, but in order to keep them below the standard, continuous monitoring may be required. Presence of these contaminants could also indicate a possible source of groundwater contamination from the landfill nearby.

Based on the results that were obtained, it can be concluded that Egg Harbor Township, which has an operating landfill located in the town has a much higher concentration of the majority of the parameters than the Middle Township, located farther away from a landfill. This indicates that the presence of a landfill in close proximity to residential areas diminishes the water quality of that area due to possible leachate percolation, even of a well monitored and managed landfill. Therefore, the hypothesis that was initially stated is supported.

\section{ACKNOWLEGMENTS}

100-K Strong Initiative, Universidad Tecnológica de Panamá, and Wilkes University.

\section{REFERENCES}

[1] Z. Han, H. Ma, G. Shi, L. He, L. Wei, and Q. Shi, "A review of groundwater contamination near municipal solid waste landfill sites in China," Sci. Total Environ., vol. 569, pp. 1255-1264, 2016.

[2] J. A. Reyes-López, J. Raml’lirez-Hernández, O. Lázaro-Mancilla, C. Carreón-Diazconti, and M. M.-L. Garrido, "Assessment of groundwater contamination by landfill leachate: A case in México,” Waste Manag., vol. 28, pp. S33--S39, 2008.

[3] S. R. Samadder, R. Prabhakar, D. Khan, D. Kishan, and M. S. Chauhan, "Analysis of the contaminants released from municipal solid waste landfill site: A case study," Sci. Total Environ., vol. 580, pp. 593-601, 2017.

[4] S. Szabó et al., "A methodology for maximizing the benefits of solar landfills on closed sites," Renew. Sustain. Energy Rev., vol. 76, pp. 1291-1300, 2017.

[5] J. Kret et al., "A respiratory health survey of a subsurface smoldering landfill," Environ. Res., vol. 166, pp. 427-436, 2018.

[6] A. C. U. A. Landfill, "Atlantic County Utilities Authority Landfill." [Online]. Available: https://wastebits.com/locator/location/atlantic-county-utilitiesauthority-landfill.

[7] N. K. A. Water, "WATER QUALITY REPORTS." [Online]. Available: https://amwater.com/njaw/water-quality/waterquality-reports.

[8] S. P. SULLIVAN, "The most toxic sites in each New Jersey county." [Online]. Available: https://www.nj.com/news/2017/04/the_most_toxic_sites_in_eac h_new_jersey_county.html.

[9] Unites States Environmental Protection Agency, "Pollutants in drinking water." [Online]. Available: https://www.epa.gov/.

[10] "The USGS Water Science Schoo." [Online]. Available: https://water.usgs.gov/edu/groundwater-contaminants.html. 